\title{
Therapeutic dilemma in patients with short cervices during pregnancy after conization
}

\author{
This article was published in the following Dove Press journal: \\ International Journal of Women's Health \\ 23 February 2017 \\ Number of times this article has been viewed
}

\author{
Shunji Suzuki \\ Department of Obstetrics and \\ Gynecology, Japanese Red Cross \\ Katsushika Maternity Hospital, \\ Tokyo, Japan
}

Correspondence: Shunji Suzuki Department of Obstetrics and Gynecology, Japanese Red Cross Katsushika Maternity Hospital, 5-I I-I2 Tateishi, Katsushika-ku, Tokyo I24-00 I2, Japan

$\mathrm{Tel}+8 \mid 336935211$

Fax +8 I 336948725

Email czg83542@mopera.ne.jp

\section{Dear editor}

We read the recent review article entitled "Prevention of preterm delivery: current challenges and future prospects" by van Zijl et al. ${ }^{1}$ However, they did not adequately discuss the prevention of preterm delivery in cases with a history of conization, or a cone biopsy of the uterine cervix. ${ }^{2,3}$ Performing a cervical cerclage has been common in the treatment of pregnant women with cervical insufficiency to prevent preterm delivery, as reported by van Zijl et al. ${ }^{1}$ However, the effect of prophylactic cerclage in women with a history of conization is little understood, because there are no prospective randomized controlled trials concerning the efficiency and risk of prophylactic cerclage in this subgroup of pregnant women. ${ }^{3-15}$ Table 1 summarizes the previous examinations concerning the effect of prophylactic cerclage in pregnancy after conization, including four English language articles searched using PubMed (Bethesda, MD, USA) and eight Japanese language articles searched using Igaku Chuo Zasshi ${ }^{\circledR}$ (NPO Japan Medical Abstracts society, Tokyo, Japan), with the key search terms of "cerclage" and "conization". ${ }^{-15}$ In these studies, statistical significances of the categorical variables were tested by $\chi^{2}$ test (with Yates's correction) or Fisher's exact test. As shown in Table 1, there have been some small retrospective population-based cohort studies in this field. In an earlier study, ${ }^{3}$ cerclage has been recommended in pregnancies following excessive cone biopsy. However, some recent studies have suggested an association between local infection in cases of short cervices related to large cones and preterm labor in women with a history of conization..$^{4-7}$ In these cases, sutures can act as a foreign body and lead to uterine irritability and contractions after a cerclage procedure..$^{5-7}$ Moreover, some authors have reported a significant increase in pathologic flora in the vagina and cervix after cerclage leading to chorioamnionitis and preterm labor. ${ }^{16}$ Thus, prophylactic cerclage is used more sparingly in pregnancies following conization in recent years. ${ }^{5-7}$

Between 2011 and 2015, 62 cases of pregnancy with a history of conization were managed at the Japanese Red Cross Katsushika Maternity Hospital. During this period, I had not performed cerclage in any cases of pregnancy with a history of conization irrespective of the cervical length. Of the 62 cases, nine cases (15\%) resulted in miscarriage or preterm delivery (18\%). In eight $(89 \%)$ of the nine cases, chorioamnionitis of the placenta was confirmed microscopically. My cases may support the latter studies, ${ }^{4-7}$ suggesting an association between infection and preterm labor in women with a history of conization.

A therapeutic dilemma exists among patients with short cervix in pregnancy after conization. 
Table I Preterm delivery rate (\%) with pregnancies after cervical conization with and without prophylactic cerclage in four English and eight Japanese retrospective population-based cohort studies

\begin{tabular}{|c|c|c|c|c|}
\hline & \multirow{2}{*}{$\begin{array}{l}\text { Preterm } \\
\text { delivery/ } \\
\text { abortion }\end{array}$} & \multicolumn{2}{|c|}{ Prophylactic cerclage } & \multirow[t]{2}{*}{$P$-value } \\
\hline & & Yes & No & \\
\hline \multicolumn{5}{|c|}{ English literature } \\
\hline $\begin{array}{l}\text { Zeisler et al, }{ }^{4} \\
1997\end{array}$ & $<37$ weeks & $23 \%(7 / 30)$ & $21 \%(8 / 39)$ & 0.78 \\
\hline Nam et al, ${ }^{5} 2010$ & $<37$ weeks & $50 \%(3 / 6)$ & $25 \%(15 / 59)$ & 0.42 \\
\hline Shin et al, ${ }^{6} 2010$ & $<28$ weeks & $8 \%(2 / 25)$ & $7 \%(2 / 3 I)$ & 0.58 \\
\hline & $<34$ weeks & $20 \%(5 / 25)$ & $19 \%(6 / 31)$ & 1.00 \\
\hline & $<37$ weeks & $36 \%(9 / 25)$ & $29 \%(9 / 31)$ & 1.00 \\
\hline & $\begin{array}{l}<37 \text { weeks } \\
(\mathrm{CL}<25 \mathrm{~mm})\end{array}$ & $25 \%(3 / / 2)$ & $43 \%(3 / 7)$ & 0.62 \\
\hline $\begin{array}{l}\text { Rafaeli-Yehudai } \\
\text { et al, }{ }^{7} 2014\end{array}$ & $<34$ weeks & $32 \%(7 / 22)$ & $6 \%(5 / 97)$ & 0.02 \\
\hline \multicolumn{5}{|c|}{ Japanese literature } \\
\hline $\begin{array}{l}\text { Nagasaka et al, }{ }^{8} \\
2002\end{array}$ & $<37$ weeks & $60 \%(3 / 5)$ & $13 \%(1 / 8)$ & 0.24 \\
\hline $\begin{array}{l}\text { Matsui et al, } \\
2008\end{array}$ & $<37$ weeks & $30 \%(3 / 10)$ & $30 \%(6 / 20)$ & 1.00 \\
\hline $\begin{array}{l}\text { Tokunaka et al, }{ }^{10} \\
2010\end{array}$ & $<37$ weeks & $\begin{array}{l}\text { Unknown } \\
(n=8)\end{array}$ & $\begin{array}{l}\text { Unknown } \\
(n=21)\end{array}$ & NS \\
\hline Muro et al," & $<34$ weeks & $6 \%(2 / 35)$ & $25 \%(3 / 12)$ & 0.06 \\
\hline \multirow[t]{3}{*}{2013} & $<37$ weeks & $20 \%(7 / 35)$ & $42 \%(5 / 12)$ & 0.14 \\
\hline & $\begin{array}{l}<34 \text { weeks } \\
(\mathrm{CL}<25 \mathrm{~mm})\end{array}$ & $0 \%(0 / 13)$ & $100 \%(3 / 3)$ & $<0.01$ \\
\hline & $\begin{array}{l}<37 \text { weeks } \\
(\mathrm{CL}<25 \mathrm{~mm})\end{array}$ & $23 \%(3 / 13)$ & $67 \%(2 / 3)$ & 0.44 \\
\hline $\begin{array}{l}\text { Tanimoto et al, }{ }^{12} \\
2013\end{array}$ & $<37$ weeks & $36 \%(4 / I I)$ & $30 \%(14 / 47)$ & 0.82 \\
\hline Ishiguro et al, ${ }^{13}$ & $<37$ weeks & $19 \%(4 / 21)$ & - & - \\
\hline 2013 & $\begin{array}{l}<37 \text { weeks } \\
(\mathrm{CL}<25 \mathrm{~mm})\end{array}$ & $50 \%(4 / 8)$ & - & - \\
\hline $\begin{array}{l}\text { Kawasaki et al, }{ }^{14} \\
2013\end{array}$ & $<37$ weeks & $17 \%(1 / 6)$ & $12 \%(7 / 58)$ & 0.75 \\
\hline Kawana et al, ${ }^{15}$ & $<33$ weeks & - & $4 \%(5 / 68)$ & - \\
\hline 2015 & $<37$ weeks & - & $18 \%(12 / 68)$ & - \\
\hline
\end{tabular}

Abbreviations: NS, not significant; CL, cervical length.

\section{Disclosure}

The author reports no conflicts of interest in this communication.

\section{References}

1. van Zijl MD, Koullali B, Mol BW, Pajkrt E, Oudijk MA. Prevention of preterm delivery: current challenges and future prospects. Int $J$ Womens Health. 2016;8:633-645.

2. Armarnik S, Sheiner E, Piura B, Meirovitz M, Zlotnik A, Levy A. Obstetric outcome following cervical conization. Arch Gynecol Obstet. 2011;283(4):765-769.

3. Leiman G, Harrison NA, Rubin A. Pregnancy following conization of the cervix: complications related to cone size. Am J Obstet Gynecol. 1980; 136(1):14-18.

4. Zeisler H, Joura EA, Bancher-Todesca D, Hanzal E, Gitsch G. Prophylactic cerclage in pregnancy. Effect in women with a history of conization. J Reprod Med. 1997;42(7):390-392.

5. Nam KH, Kwon JY, Kim YH, Park YW. Pregnancy outcome after cervical conization: risk factors for preterm delivery and the efficacy of prophylactic cerclage. J Gynecol Oncol. 2010;21(4):225-229.

6. Shin MY, Seo ES, Choi SJ, et al. The role of prophylactic cerclage in preventing preterm delivery after electrosurgical conization. J Gynecol Oncol. 2010;21(4):230-236.

7. Rafaeli-Yehudai T, Kessous R, Aricha-Tamir B, et al. The effect of cervical cerclage on pregnancy outcomes in women following conization. J Matern Fetal Neonatal Med. 2014;27(15):1594-1597.

8. Nagasaka I, Takamoto M, Saito M, et al. [Outcomes of cervical cerclage in pregnancy after conization]. Kanto J Obstet Gynecol. 2002; 39(2):175. Japanese.

9. Matsui T, Usui R, Okuchi A, et al. [Preterm delivery rate in pregnancy after conization in a cohort study]. J Jpn Soc Perin Meon Med. 2008; 43(2):461. Japanese.

10. Tokunaka M, Otsuki K, Matsuura R, et al. [Management of pregnancy after conization]. Acta Obstet Gynaecol Jpn. 2010;62(2):643. Japanese.

11. Muro M, Nakahashi H, Tanaka T, Noguchi M, Tsumura K, Yokoyama M. [The effect of cervical cerclage in pregnancy after conization]. Obstet Gynecol Pract. 2013;62(3):417-423. Japanese.

12. Tanimoto H, Okamoto K, Takao Y, Honda H, Teramoto M, Teramoto H. [Obstetric outcomes in pregnancy after conization]. Clin Gynecol Obstet. 2013;67(1):193-196. Japanese.

13. Ishiguro $\mathrm{H}$, Kurabayashi $\mathrm{T}$, Tominaga $\mathrm{M}$, et al. [Clinical examination of cervical cerclage after cervical conization]. J Niigata City Hospital. 2013; 34(1):8-12. Japanese.

14. Kawasaki A, Kurioka H, Miyamoto J, et al. [Obstetric outcomes following cervical conization]. Mod Trends Obstet Gynecol. 2013;62(1): 117-121. Japanese.

15. Kawana Y, Adachi T, Nakabayashi Y, et al. Outcomes in pregnancy after conization without cervical cerclage. Obstet Gynaecol Jpn. 2015;67(2):961.

16. Charles D, Edwards WR. Infectious complications of cervical cerclage. Am J Obstet Gynecol. 1981;141(8):1065-1071. 


\section{Authors' reply}

Maud D van Zijl'

Bouchra Koullali'

Ben WJ Mol'

Eva Pajkrt'

Martijn A Oudijk'

'Department of Obstetrics and Gynecology, Academic Medical Center (AMC), Amsterdam, the Netherlands; ${ }^{2}$ Robinson Institute School for Reproductive Health and Pediatrics, University of Adelaide, Adelaide, SA, Australia

Correspondence: Martijn A Oudijk

Department of Obstetrics and Gynecology, Academic Medical Center, Meibergdreef 9, I I 05 AZ Amsterdam, the Netherlands

Tel +3I 205667204

Email m.a.oudijk@amc.nl

\section{Dear editor}

We have read the response by Dr Suzuki with interest, and we agree with Dr Suzuki that our paper does not discuss preventive measures in cases with a history of conization. However, in our opinion, there is currently insufficient evidence of benefit from a cerclage in this specific group.

It is known that women with a prior excisional procedure have a higher risk of preterm birth. ${ }^{1-3}$ As Dr Suzuki already points out, there are no randomized controlled trials that focus on the prevention of preterm birth in these high-risk women. So far, literature on the best strategy to prevent preterm birth after cone biopsy is lacking. Therefore, our paper does not give clear advice on how to treat these cases.

Kindinger et $\mathrm{al}^{4}$ recently described a preventive strategy in 725 women postconization. They report that a targeted monofilament cerclage can reduce preterm birth rates in women with a history of cone biopsy. However, they also notice that a reduction of cervical length of $<10 \%$ between two time points indicates a term birth and these women can be excluded from cervical length follow-up.
We do strongly emphasize the importance of a randomized controlled trial that evaluates interventions such as a cervical pessary and cerclage for the prevention of preterm birth in women with a short cervix after cone biopsy or conization. A small German prospective pilot study among 21 patients evaluated the placement of a cerclage pessary in women with at least one cold knife conization between 2010 and $2013 .^{5}$ The aim of this study was to investigate the mean interval between pessary placement and delivery. Mean cervical length measurement at pessary placement was $19 \mathrm{~mm}$ (range 4-36 mm) at a mean gestational age of 17+2 weeks of gestation $\left(10^{+5}-24^{+0}\right.$ weeks $)$. The included women did not receive progesterone. Mean interval between pessary placement and delivery was 145 (87-182) days, resulting in a mean gestational age at delivery of $38+0\left(31^{+1}-41^{+0}\right)$ weeks. Further randomized controlled trials are necessary to truly assess the effectiveness of these treatments in women with a short cervix after conization.

\section{Disclosure}

The authors report no conflicts of interest in this communication.

\section{References}

1. Berghella V, Pereira L, Gariepy A, Simonazzi G. Prior cone biopsy: prediction of preterm birth by cervical ultrasound. Am J Obstet Gynecol. 2004;191(4):1393-1397.

2. Conner SN, Frey HA, Cahill AG, Macones GA, Colditz GA, Tuuli MG. Loop electrosurgical excision procedure and risk of preterm birth: a systematic review and meta-analysis. Obstet Gynecol. 2014;123(4):752-761.

3. Danhof NA, Kamphuis EI, Limpens J, van Lonkhuijzen LR, Pajkrt E, Mol BW. The risk of preterm birth of treated versus untreated cervical intraepithelial neoplasia (CIN): a systematic review and meta-analysis. Eur J Obstet Gynecol Reprod Biol. 2015;188:24-33.

4. Kindinger LM, Kyrgiou M, MacIntyre DA, et al. Preterm birth prevention post-conization: a model of cervical length screening with targeted cerclage. PLoS One. 2016;11(11):e0163793.

5. Kyvernitakis I, Khatib R, Stricker N, Arabin B. Is early treatment with a cervical pessary an option in patients with a history of surgical conisation and a short cervix? Geburtshilfe Frauenheilkund. 2014;74(11): 1003-1008.

Dove Medical Press encourages responsible, free and frank academic debate. The content of the International Journal of Women's Health 'letters to the editor' section does not necessarily represent the views of Dove Medical Press, its officers, agents, employees, related entities or the International Journal of Women's Health editors. While all reasonable steps have been taken to confirm the content of each letter, Dove Medical Press accepts no liability in respect of the content of any letter, nor is it responsible for the content and accuracy of any letter to the editor.

\section{Publish your work in this journal}

The International Journal of Women's Health is an international, peerreviewed open-access journal publishing original research, reports, editorials, reviews and commentaries on all aspects of women's healthcare including gynecology, obstetrics, and breast cancer. The manuscript management system is completely online and includes a very quick and fair peer-review system, which is all easy to use. Visit http://www.dovepress.com/testimonials.php to read real quotes from published authors. 